\title{
Impact of the agricultural technology transfer to the production of independent palm oil smallholders: a review
}

\author{
Syarifudin, S.M. and "Zareen, Z. \\ Faculty of Plantation and Agrotechnology, Universiti Teknologi MARA Melaka Branch, Jasin Campus, \\ 77300 Merlimau, Melaka
}

\section{Article history:}

Received: 16 April 2021

Received in revised form: 1 July 2021

Accepted: 30 November 2021

Available Online: 12

December 2021

\section{Keywords:}

Palm Oil,

Smallholder,

Technology transfer

DOI:

https://doi.org/10.26656/fr.2017.5(S4).007

\begin{abstract}
Oil palm is the most efficient oil crop that is vital to oil commodity due to its versatility for being a practical raw material in producing a number of commercial products globally. Therefore, the supply of palm oil is believed to increase in order to meet the growing demand of the world population. Malaysia is the second-largest palm oil exporter in South -East Asia after Indonesia with $40 \%$ of the total output is contributed by Malaysia's smallholders. However, reports stated that the yield among smallholder's plantations is low and eventually will affect the national Gross Domestic Products (GDP). In 2019, Malaysia's palm oil total GDP was estimated to be 38.24 billion Malaysian Ringgit (MYR). In relation to the issue, low yield among the smallholders is believed to be caused by the lack of application and awareness of current technology available to aid plantation operation. Hence, agricultural technology transfer is the modern agricultural invention to improve oil palm production productivity. A review paper on the agricultural technology transfer was carried out to identify the impact of the technology transfer on palm oil smallholders' production. This approach encompassed the introduction of technology to smallholders, the technology transfer process and technology applications awareness for smallholders. The data was collected through reading on research papers, especially on productivity and engagement of smallholders on the understanding of the technology transfer through the questionnaire. The review concluded that smallholders had practised a good agricultural practice. However, low productivity was caused by the inadequate inputs among the farmers regarding the available technology, crop protection and management. Therefore, technology transfer and technology recommendation is proven to effectively help broaden smallholders' inputs and knowledge to increase their socioeconomic status and plantation productivity.
\end{abstract}

\section{Introduction}

Over the coming decades, palm oil demand is expected to increase due to the increasing world population and the increased per capita living standards. Malaysia and Indonesia are the world's leading producing countries for palm oil as stated by FAOSTAT (2016) that covers $34 \%$ of the vegetable oil consumption globally (Rahman, 2020). Production of palm oil in Malaysia has been steadily increasing since the independence of Malaysia in 1957. The annual export value of 5.6 million hectares of planted areas is RM 60 billion in 2015 (MPOB, 2016) and as reported by Ahmad et al. (2020), back in 2017 oil palm export value had reached up to RM77.85 billion which has contributed to Malaysian commodity earnings by $56 \%$. In 2015, Malaysia was recorded as the second-largest palm oil producer globally and produced $31.8 \%$ of the world's manufactured products (MPOB, 2016). Contribution of the national palm oil production involves numbers of smallholder farmers, a significant group of upstream palm oil asset producers, who make an actual effort to expand palm oil cultivation. Smallholder farmers are essential independent agents to boost domestic palm oil yields and industry growth (Perez et al., 2016). The smallholder sector in Malaysia can be divided into two groups, which are independent and organized smallholders. Independent smallholders are oil palm farmers who do not get direct assistance from the government or any other organization. On the other hand, organized smallholders are oil palm farmers who are funded by any organization or government offering agricultural input, technical assistance, or financing such as RISDA, FELCRA, and FELDA (Yew et al., 2016). 
Malaysia's region planted with oil palms has seen a substantial increase by the independent smallholder sector. In Peninsular Malaysia, a significant number of independent smallholders had 175,630 of them (MPOB,2017), with a total planted area of 538,490 hectares in 2017 (Azman et al., 2018). A large number of smallholders leave a significant impact on the national economy as numbers of registered smallholders reported gaining lower yields than large-scale plantations (IFC, 2013). Based on Nagiah and Azmi (2012); Farouque and Takeya (2007) indicated that palm oil smallholders are still in complexity in terms of best farm management practices, acquisition of new technologies, lack of financial resources and income as well as the financial ability to purchase high-quality fertilizers. Moreover, since the majority of smallholders come from a poorly educated background, this has caused them to have lack of technology awareness that can aid them in performing plantation operation activities as reported by Awang et al. (2016), smallholder cultivators commonly lived in a rural areas with low Internet coverage and current technology availability.

Complexity faced by the smallholder has brought up the term of 'agricultural technology transfer' intended by exposure to agricultural inventions, improved practices, or developments that are formally transmitted in the agricultural sector by a representative from research institutions. The conventional agriculture technology transfer studied by Azumah et al. (2018) said the most effective method with the highest mean rank is the farmer to farmer approach, followed by farmer-led technology, household and individual extension which those that have encountered with the latest technology application in the agricultural industry. However, this paper covers the modern agricultural technology transfer focusing on the presence of agricultural extension which aims to educate and assist cultivators on how science farming technology enhance expertise in handling farm operation and help to improve their economic status. Agricultural extension services aim to provide farmers with the skills they need to undertake enhanced farms, timely information, improve practices in an easy-tounderstand way, accommodate their literacy and awareness level and develop a conducive approach to innovation change (Aremu et al., 2015). Pusat TUNAS officers currently include independent smallholder farmers in a sustainability innovation cycle using RSPO principles. Thus, with the presence of technical guidance and advisory to give information and extension to independent smallholders from a qualified representative these will improve their knowledge and exposure in the oil palm operation and management. In fact, the expertise provided can also solve the constraints experienced by smallholders with an expansion of their knowledge on new technologies that can be utilized in conducting the oil palm operation efficiently. Hence, this review is aimed to assess the technology transfer by practising, a sustainable agricultural approach, illustrate the impacts on smallholders' productivity and suggest the technology recommendation that is suitable for smallholders' cultivators with reference to associated literature.

\section{Introduction of technology to smallholder}

\subsection{Oil palm smallholder}

Private estates dominate Malaysia's oil palm industry with $60 \%$ whereas $40 \%$ is covered by the smallholding scheme. The country's smallholding scheme is led by the Federal Land Development Authority (FELDA) of the country, which was set up in 1956 . It represents $29 \%$ of all smallholder farmers in the country and remains $11 \%$ of independent smallholder farmers (Abazue et al., 2015).

In summary, the smallholder is commonly described as having not more than 40 hectares of land (Table 1) with land title or customary rights holders (Awang et al., 2016). It can be divided into two principal groups (Abdullah 1991; Department of Statistics Malaysia, 2015). First, organized smallholder growers who cultivate oil palm through either government or any technical assistance, input, or supporting agency (FELDA, FELCRA, RISDA). Secondly, independent smallholder farmers grow oil palm without direct private organization or government funding (Yew et al., 2016). Vermeulen and Goad (2006) stated independent smallholders are farmers who grow oil palm without direct input and sell their crops directly or through traders to local mills. In Malaysia, small farmers multiply as small mills, and FELDA schemes grow to minimize regulation and subsidies. While RSPO (2010) stated that independent smallholders are financially autonomous farmers who determine how to improve their land best, what crops to grow, and how best to manage it. They are not bound by a specific mill or department, thus government agencies may fund or expand them.

\subsection{Planted area of independent smallholder}

Based on Azman et al. (2018), a significant number of the independent smallholders were in Peninsular Malaysia with a total planted area of 175630 of them in 2017 of 538490 hectares (Table 2). Most of them are in Johor, which is 76463 (30.7\% of the total number in the country), followed by Perak (17.8\%), Sarawak (15.3\%), Sabah (14.2\%) and Selangor (8.7\%), with the remaining states accounting for $13.3 \%$. The independent smallholders in Johor also owned the largest area in 
Table 1. Distribution of oil palm planted area by category in Malaysia (2016 -2017)

\begin{tabular}{lcccc}
\hline & \multicolumn{4}{c}{ Hectare } \\
\cline { 2 - 5 } Category & \multicolumn{2}{c}{2016} & \multicolumn{3}{c}{2017} \\
\cline { 2 - 5 } & ha & ha & ha & $\%$ \\
\hline Private estates & 3508554 & 3508554 & 3543429 & 61 \\
Government schemes & 951169 & 951169 & 940326 & 16.1 \\
State schemes/government agencies & 344314 & 344314 & 347632 & 6.0 \\
Independent smallholders & 933948 & 933948 & 979758 & 16.9 \\
Total & 5737985 & 5737985 & 5811145 & 100 \\
\hline
\end{tabular}

Source: MPOB (2018)

Table 2. Number and oil palm planted area of independent smallholders in Malaysia, 2017

\begin{tabular}{ccccc}
\hline State & Number & \% & Area (ha) & \% \\
\hline Johor & 76463 & 30.7 & 223424 & 22.8 \\
Perak & 44214 & 17.8 & 123511 & 12.6 \\
Selangor & 21719 & 8.7 & 46386 & 4.7 \\
Kedah & 5832 & 2.3 & 26650 & 2.7 \\
Negeri Sembilan & 5586 & 2.2 & 26090 & 2.7 \\
Terengganu & 3327 & 1.3 & 12922 & 1.3 \\
Melaka & 2918 & 1.2 & 12675 & 1.3 \\
Pulau Pinang & 1853 & 0.7 & 9303 & 0.9 \\
Kelantan & 1735 & 0.7 & 5977 & 0.6 \\
Perlis & 17 & 0 & 90 & 0 \\
Peninsular Malaysia & $\mathbf{1 7 5 6 3 0}$ & $\mathbf{7 0 . 5}$ & $\mathbf{5 3 8 4 9 0}$ & $\mathbf{5 5}$ \\
Sabah & 15342 & 14.2 & 221139 & 22.6 \\
Sarawak & 38057 & 15.3 & 220129 & 22.5 \\
Sabah and Sarawak & $\mathbf{7 3 3 9 9}$ & $\mathbf{2 9 . 5}$ & $\mathbf{4 4 1 ~ 2 6 8}$ & $\mathbf{4 5}$ \\
MALAYSIA & $\mathbf{2 4 9} \mathbf{0 2 9}$ & $\mathbf{1 0 0}$ & $\mathbf{9 7 9} \mathbf{7 5 8}$ & $\mathbf{1 0 0}$ \\
\hline
\end{tabular}

\section{Source: MPOB (2017)}

terms of planted areas, representing 223,424 hectares, or $22.8 \%$ of the total oil palm area owned by independent smallholders in Malaysia. Moreover, the smallholders in Sabah owned the second-largest area, 221,139 hectares (22.6\%), followed by those in Sarawak and Perak, with 220,129 and 123,511 hectares, respectively. The average oil palm area per independent smallholder in Malaysia was 3.93 hectares. In contrast, the average area per independent smallholder in Peninsular Malaysia, Sabah and Sarawak were 3.07, 6.26 and 5.78 hectares, respectively, on a regional basis

\subsection{Oil palm fresh fruit bunch yield of independent smallholder}

Mohd Ishak and Abd Manaf (2020) analyzed that the smallholders average Fresh Fruit Bunch (FFB) yield was between 14.0 to 18.0 tonnes/hectare/year, slightly lower than the national average of 18 to 22 tonnes/hectare /year as show in Table 3.

\subsection{Smallholder characteristics}

According to Aniedu et al. (2007), smallholder farmers were in their late years in the range of 50 years of age and above which also be supported by Ain Sophia et al. (2017) and Jaafar et al. (2017). On average, the age of the smallholder was 58 years (Azman et al., 2018). The majority of the smallholders were uneducated below than lower secondary educational qualification and a few have upper secondary school qualification (Awang et al., 2016; Ain Sophia et al., 2017; Jaafar et al., 2017; Azman et al., 2018; Ishak, 2020). Awang et al. (2016) indicated most of them are full-time smallholders and others are only part-time growers as mentioned in Jaafar et al. (2017) and Ain Sophia et al. (2017). The part-time growers in the smallholder's domain are mainly reported to be government servants, self-employed, private sector employees, and others such as taxi or lorry drivers (Azman et al., 2018). Based on oil palm cultivation observation, the independent smallholder had more than

Table 3. Oil palm FFB yield of independent smallholder (2012-2018)

\begin{tabular}{lccccccc}
\hline \multirow{2}{*}{ REGION } & \multicolumn{7}{c}{ FFB YIELD (THA-1 YR-1) } \\
\cline { 2 - 8 } & 2012 & 2013 & 2014 & 2015 & 2016 & 2017 & 2018 \\
\hline Peninsular & 18.87 & 19.14 & 18.49 & 17.57 & 14.29 & 17.74 & 17.11 \\
Sabah & 18.52 & 15.49 & 15.42 & 16.10 & 14.47 & 14.88 & 15.72 \\
Sarawak & 16.82 & 17.84 & 18.49 & 17.87 & 17.32 & 17.90 & 17.54 \\
Malaysia & 18.53 & 18.21 & 18.00 & 17.33 & 16.12 & 17.19 & 16.90 \\
\hline
\end{tabular}

Source: MPOB (2019) 
ten years of oil palm experience. Whereas the number of years of experience in the range below one year was the lowest (Jaafar et al., 2017) and (Ishak, 2020).

\section{Technology transfer process}

\subsection{Agricultural technology transfer to smallholders}

The technology transfer is transmitted or disseminated from locations and communities to consumers in broader audiences elsewhere. Even after their various interpretations, the fundamental concept of technology transfer is from one or more donor sources to another recipient, a transfer of know-how, technological expertise and/or technology seems to be shared by different opinions (Roxas et al., 2011). The idea of extension education was invented by the University of Cambridge, founded in 1873 , to explain ordinary people's efforts for universities' educational advantages (Maunder 1972; Jones and Garforth 1997; Leeuwis and Van Den Ban, 2004). Maunder (1972) further described the extension as an extension or a programme or method that extends an institution's educational advantages to individuals who are unable to make use of them normally.

In this regard, Maunder (1972) defined agricultural extension as a service or system that supports farmers in improving their farming techniques, application, and living standards, raises the social and educational standards of rural life, and increase production efficiency and income. Technology transfer is commonly delivered by an extension agent and as stated by Coombs and Ahmed (1974), there are different modes of extension and one of them is short-term training where it is considered as non-formal agricultural education. Nevertheless, the extension conveys multiple meanings to different people (Roling, 1982) since it is structured in numerous ways to achieve a broad range of goals (Swanson and Claar, 1984) and has evolving definitions (Leeuwis and Van Den Ban, 2004) in parallel, extension services which undergone serious changes and transitions over time especially since the $1980 \mathrm{~s}$, and remain in transition (Cristóvão et al., 2012; Rivera and Qamar, 2013).

However, the community views extension as a government tool for supporting agricultural production improvement techniques (Roling, 1982). Nagel (1997) argued the extension was historically built as the right way to pass "modern" research findings to the "traditional" farmer. In summary, the extension is identified more or less internationally with transfer technology and the propagation of creative theory. The transfer technology model of the research extension farmer connection was based on combining the general belief in science and commitment to modernization and the dissemination of innovation theory principles (Roling, 1988; Nagel, 1997). To facilitate the adoption of innovations by farmers, for instance, to carry out their primary function, as Lamble (1984) stated, extension professionals, need to have a good understanding of processes involved in the dissemination of innovations, which in turn provide the basis for the development of effective extension programmes strategies. Based on Aremu et al. (2015) and Salako et al. (2015), extension workers needed practical guidance and advice to allow farmers to implement new technology properly. The active participation of farmers will encourage them to gain new knowledge, be open to changes and spread agricultural technology to other farmers' (Asiabaka, 2002; FAO, 2001).

The agriculture programme was designed to move technology from researchers to smallholders (Hawkins and Van den Ban, 1996). The transferal of knowledge, attitude, and skills to smallholder farmers is an enabling environment, particularly for smallholder problems (Awang et al., 2016). Stuart et al. (2011) and Waddington and White (2014) indicated that the agricultural extension programme improves indigenous farmers' experience with the latest information and skills for efficient farming and farm management practices. Farm productivity can also be improved by the utilization of technical components such as good agricultural practices (GAP) during the extension programme (Mariyono, 2009).

\subsection{Oil palm guidance and advisory programme}

Through the guidance and advisory programme (Tunjuk Ajar Nasihat Sawit/TUNAS), the MPOB was responsible for carrying out various technology transfer activities to a target group of independent smallholders. This programme was set up in 2002 and started to operate in January 2003. Its main objective is to help the productivity and socio-economic status of smallholders increase. At the initial stages, special training in oil palm technology was given to 50 extension officers appointed by the MPOB. Since the programme's establishment, the number of extension officers in 52 regional offices and branches has increased to 265 officers due to urgency. Senior officers who are responsible for planning and implementing technology transfer activities in their respective areas are 168 out of 265 extension officers. In guiding the independent smallholders, extension officers are specially trained and equipped with sufficient knowledge of new oil palm technologies, management, planting and agronomic practices (Abdul Wahab et al., 2018). The MPOB believes that smallholders' technical knowledge and skills can increase their oil palm productivity in line with the government's target of 22 
tonnes/hectare/year by 2020 (Khairuman et al., 2014).

\subsection{Competency performance relationships}

The relation between talent and success as well known as competency is closely linked to success. It means that professional extension staff is more successful in delivering their task. Dhanakumars (2001) and Linders (2001) mentioned that work performance and extension competencies are positively related. This notion is further supported by Armstrong (2003) that competencies contribute to the high level of success between individuals and organizations. On the other hand, it is possible to improve an extension company's ability to serve its customers better by establishing several competencies and including those competent in the training (Liles and Mustian, 2004). In return, this will certainly raise the rate of consumers' acceptance of new technologies.

Riggo and Tylor (2000) indicated that possession of social skills contributed to a strong prediction of employment success. An extension worker must also make the material accessible to many smallholder identities, races, cultures, and religions. Being confident when communicating and using terms with a local dialect are fundamentally convincing for people to embrace innovative technologies (Awang et al., 2016). Research findings showed that social skills are the greatest contribution of all the individual factors to explaining the success of extension staff (Thach et al., 2008). Rezaie et al. (2008) has found that $48.6 \%$ of the labour performance variance of extension employees is attributed to the regression study performed by Rezaie in the labour output review of experts in agricultural extension in Iran.

Extension employees must be equipped and knowledgeable in their employment's technological sector concerning emerging technology expertise and skills. As indicated by Tiraieyari et al. (2009), the employee work output is positively connected with the technical aspect of their work with GAP $(\mathrm{p}=0.001 ; \mathrm{r}=$ 0.356). Boyd (2003) also substantiated that a good extension staff should have clear technological knowhow and skills (competence). Additionally, the study by Belay and Abebaw (2004) has a similar finding that higher customer technology rates are reached when extension staff has sufficient technical skills.

According to Olsen et al. (2006), cultural skills have also become important for service providers, agencies, and specialists. As the extension is a non-formal education feature for all institutions/agencies that distribute information to improve people's skills, attitudes, qualifications and expectations (Rivera and
Qamar, 2003), cultural competencies are also a requirement for extenders and extension staff.

As mentioned by Tiraieyari (2009), extension workers' output is positively linked to the cultural competencies $(p=0.001 ; r=0.611)$. This extension of expertise allows workers to represent all rural residents, cross-cultural gaps and eventually enhance the results and accomplishments of extension.

\section{Technology applications awareness for smallholder \\ 4.1 Important knowledge and skill}

Generally, we use machinery, technology, procedures, skills, production techniques, and physical methods in performing field operations. They allow for control and alterations of objects that are of interest or specific requirements. Moreover, they also utilize a host of tools and processes in which they are manufactured. Based on Abdul et al. (2016), additional knowledge and new skills and changes in farmers' attitudes must now be implemented to further develop the agricultural sector, particularly in developing countries. Therefore, human resources development through agricultural education and training is an essential component in all agricultural growth strategies.

Meanwhile, technology transfer involves efforts to develop the country and society through the absorption of technology. It is a process in which technical information is available originated from a particular institutional environment, utilized by people in an institutional environment (Jedlicka, 1977). Smallholders in the theory of human capital may boost their productivity by acquiring knowledge, skills, and an attitude to sustainable agriculture (Becker, 1962). While Rogers (1992) and Rogers (2003) emphasized farm efficiency, the learning process started from understanding new information, and practice needs that had been learned can be improved.

\subsection{Impact of technology transfer}

According to Pierre-Andre et al. (2010), most farmers need to be educated in crop processing, harvesting techniques, stimulant preparation, and better agricultural techniques. Meanwhile, Al-Shadiadeh (2007) in his study found that rural farmers to be trained because most of them do not have sufficient information regarding the plantation field operation and management. This is further supported by Godtland et al. (2003) that farmers who participate in training programmes are more aware of integrated practices in the management of pests than farmers who do not participate in such programmes. 
Moreover, Mariyono (2011) has proven that the use of technology in pests integrated management has effectively enhanced farmers' production. In their research, Witt et al. (2006) mentioned that training and guidance programmes for farmers will not only increase the acceptance and dissemination of agricultural knowledge but also help farmers who are trained in the community. In return, there will be an increase in farmers' productivity and income with the presence of adequate knowledge, training, skills, handling technology and proper equipment. Tauer (1998) has found that the increasing productivity of dairy farmers in New York has resulted from new technological practices. The GAP between real productivity and potential productivity can be overcome by increasing the rate of transfer of technologies and knowledge of smallholders to help them improve effective farm management practices (Anderson and Feder, 2003; Feder et al., 2004).

Based on the statistics, the increase in oil palm productivity is due to the wider oil palm plantation region. GAP, mechanization implementation, and explicit materials and procedures will achieve high productivity (Wahid and Simeh, 2009). This can be supported by Kushairi et al. (2018) who posited improved mechanization, integrated pesticide and Ganoderma control, advanced biotechnology and breeding, and GAP help to increase oil palm yields for private plantations well as smallholdings companies. Furthermore, Kannan et al. (2017) stated that to reduce smallholder production loss due to red disease caused by Ganoderma fungus, technology transfer to counter the issue to smallholders is necessary. Therefore, adequate training and courses must be performed repeatedly to develop smallholders' skills to minimize the infestation and spread of the aforementioned disease.

As argued by Fauziah et al. (2018), the replanting programme with good planting materials has shown that Malaysian oil palm productivity has been increasingly successful. Since 2011, under the 10th Malaysian programme, the 'Replantation and New Planting Assistance Scheme' programme has been implemented for independent smallholders. Assistance includes soil preparation, oil palm seedlings, fertilizer and other farming inputs. The scheme has given farmers the ability to boost their productivity (Abd Manaf et al., 2017). As stated by Azian et al. (2017), 66.1\% of the 663 independent oil palm farmers are aware of sustainable farming practices. It is evident that knowledge transfer through direct interaction between small farmers and their respective extension agents has been successful and led to better land management. Smallholders currently appear to focus more on informal programmes to speed up learning, emphasizing the importance of a strong social network in the area. According to Sahidan et al. (2019), having good connections or networks amongst smallholders within society seemed to impact FFB productivity positively. However, the study by Tan et al. (2019) pointed out that independent small farmers appeared to have poorly run farms concerning fertilizers application and management. The study found that respondents generally know the content of fertilizers and their application methods nevertheless do not know how to identify the symptoms of nutrient deficiency in oil palm thus leaving the problem unsolved. This overlooked issue reflects the inefficiency of prior fertilizer application. As such, issues related to the dysfunction of fertilizer management should not occur as it accounts for $60 \%$ of the overall cost of production.

Based on Awang et al. (2016) a report from Oil Palm Guidance and Advisory Programme (TUNAS) has shown that independent smallholders have taken up critical farm management capacities to gain a high yield production. Current productivity rose from 12.87 tonnes/ hectare in 2015 to 17.18 tonnes. With an average price of RM 353.00 per tonnes for a fresh fruit bunch (FFB), smallholders would produce gross revenue of RM 6.064.54 per hectare. While, Jalani et al. (2002) further argued that the same location would generate FFB yields of 20 tonnes/hectare with $20 \%$ of OER, which could translate to $1,373,368$ tonnes of oil with good extension services. The net increase in the oil yield will be 403083 tonnes with a sum of RM 463545450 (price @ RM 1150/tonnes) (Table 4). This will be a major additional income for smallholder farmers. A similar finding in Azian et al. (2017) shows the average 2014 production of FFB was 15.00 tonnes per hectare/year in the study area. In 2015, the average production for FFB was 19.17 tonnes per hectare/the year 2015. This shows that the Good Agricultural Practices (GAP) developed Malaysian Palm Oil Board, which TUNAS, has a positive effect on the increase in productivity in the field of research.

Moreover, Awang et al. (2016) indicated that small farmers following the degree of good agricultural practices employed by TUNAS has a different productivity level. The study results disclosed the estimated annual total production of FFB is set at 11.81 tonnes per hectare per year. However, the average total FFB production recorded this month is 0.984 tonnes/ hectare. This productivity has not yet met MPOB's annual goal of 22 tonnes/hectare and only smallholders with good farming practices can earn more than RM 3,501 a month.

Furthermore, an observation-based study by Ishak (2020) showed that respondents with a low perception of the Oil Palm Seedling Assistance Scheme (SBABB) 
Table 4. Cost benefit of intensive extension to smallholders

\begin{tabular}{|c|c|c|}
\hline \multicolumn{3}{|c|}{1 Current situation (2001) } \\
\hline & a. Total area of independent smallholders & 343342 ha \\
\hline & b. Average FFB yield & $15 \mathrm{t} / \mathrm{ha}$ \\
\hline & c. Oil yield at $18.44 \%$ OER & $970285 \mathrm{t}$ \\
\hline & d. Income (c x RM 1150/t) & RM 1115827750.00 \\
\hline \multicolumn{3}{|c|}{2 After intensive extension } \\
\hline & e. Expected increase in FFB yield & $20 \mathrm{t} / \mathrm{ha}$ \\
\hline & f. Expected oil yield at $20 \%$ OER & $1373368 \mathrm{t}$ \\
\hline & g. Expected income (f x RM 1150/t) & RM 1579373200.00 \\
\hline & h. Difference in oil yield (f - c) & $403083 \mathrm{t}$ \\
\hline & i. Difference in income (g d) & RM 463545450.00 \\
\hline \multicolumn{3}{|c|}{3 MPOB } \\
\hline & j. Expected increase in cess income (h x RM 9) & RM 3627747.00 \\
\hline & k. Cost to employ 50 extension technicians per year & RM 900000.00 \\
\hline
\end{tabular}

Source: Jalani et al. (2002)

achieved inferior yields. This can be seen in Table 5; a cross-table analysis of the independent output variables. This study showed that respondents with a medium level of perception of an SBABB scheme had a higher FFB output than farmers who claimed a strong SBABB perception. Moreover, in the technology transfer which requires smallholders to adhere and adopt the GAP, it is estimated that the FFB yield will increase by at least $30 \%$ from the present productivity within three years (Nurhanani, 2016). As posited by Ishak (2020), the average smallholder yield from fresh fruit bunch (FFB) was 14.0 to 18.0 tonnes/hectare/year, which was much lower than the national average of 18-22 tonnes/hectare/ year (Table 3). However, with the GAP's successful implementation, small farmers can achieve an excellent return of up to 30 tonnes/hectare/year, as shown by the 30 club members (Idris, 2007).

\subsection{Factors affecting farmer's acceptance of technology}

The independent productivity output of the oil palm smallholder is seen as agricultural entrepreneurship. Their success depends on the facilitator's expertise, good practices in agriculture, smallholder qualities and farm properties (Awang et al., 2016). In a number of local studies by Abu Samah et al. (2009) and Hayrol Azril et al. (2009), they have agreed with findings by Abdullah and Samah (2013), which focused on factors such as negative perception, education, small land areas, lack of capital, inadequate infrastructure facilities, and the limited capacity of extension workers as the key drivers that led to the low adoption of technology. Furthermore, factors such as methods of organization and management of extension programmes, local conditions are also highlighted as the drivers for technology adoption and the knowledge level of extension workers.

Moreover, Zulkefli and Syahrizan (2017) indicated that the adoption of innovation by an individual depends not only on an individual's behaviours but also on organizational strategies, methods, and behaviour. Organizations must have criteria to promote the nature

Table 5. Cross tabulation between KAS, perception towards MPOB and SBABB and FFB yield

\begin{tabular}{|c|c|c|c|c|}
\hline \multirow[b]{2}{*}{ Variables } & \multirow[b]{2}{*}{ Categories } & \multicolumn{3}{|c|}{ Yield categories (t/ha/yr) } \\
\hline & & $\begin{array}{c}\text { Lower } \\
(1.00-10.99)\end{array}$ & $\begin{array}{c}\text { Medium } \\
(11.00-20.99)\end{array}$ & $\begin{array}{c}\text { Higher } \\
(21.00-39.99)\end{array}$ \\
\hline \multirow[t]{3}{*}{ SBABB } & Poor & 16 & 7 & 0 \\
\hline & Medium & 33 & 52 & 11 \\
\hline & Good & 6 & 48 & 7 \\
\hline \multirow[t]{3}{*}{ MPOB } & Poor & 9 & 7 & 0 \\
\hline & Medium & 41 & 51 & 14 \\
\hline & Good & 5 & 49 & 4 \\
\hline \multirow[t]{3}{*}{ Knowledge } & Poor & 1 & 2 & 0 \\
\hline & Medium & 48 & 49 & 7 \\
\hline & Good & 6 & 56 & 11 \\
\hline \multirow[t]{3}{*}{ Attitude } & Poor & 13 & 55 & 5 \\
\hline & Medium & 31 & 39 & 5 \\
\hline & Good & 11 & 13 & 8 \\
\hline \multirow[t]{3}{*}{ Skill } & Poor & 24 & 7 & 1 \\
\hline & Medium & 29 & 66 & 10 \\
\hline & Good & 2 & 34 & 7 \\
\hline
\end{tabular}

Source: Ishak (2020) 
and form of assistance to individuals that would impact their use of innovation. Facilitating requirements include the provision of training and assistance. Education, management support and incentives are organizational considerations. Corporate influences can inspire workers to innovate. Chan et al. (2013) found that inadequate available training programmes and government resources contributed to the inability to develop adequate modern smallholders. Also, the factors that influence technology use include farmers' expectations and education, awareness of extension staff, management of the extension programme and the physical conditions in the field (Truong, 2008).

Furthermore, the degree of acceptance of oil palm mechanization studied to be lack sensitivity, expertise and a low-cost mechanic purchasing force (Nwaobiala and Ezeh, 2012). The availability and abundance of lowcost foreign labour is a priority choice for smallholder producers and goes beyond mechanized equipment. The use of mechanization in the field is too expensive for smallholders. In addition, there is a low acceptance of mechanization and technology because of restricted machinery access to oil palm plantations and narrow terraces in hilly regions, in particular, during plant operations (Ain Sophia and Sophia, 2017). Therefore, the propensity to use foreign labour was raised.

In 2014, the sector consisted of 488,090 farmers and this figure grew to 497,840 in 2015 comprising 369,076 farmers from Indonesia (Kementerian Dalam Negeri Malaysia, 2015). The introduction of mechanization would reduce the reliance on foreign labour and overall plantation labour cost for numbers scope of work.

Social influence is the degree to which the adoption of technology by members of a social community affects it. Employees may embrace innovation, not due to its utility but because of the social pressure they perceive. Such pressure may be experienced by people with important views and opinions, including in the social networks. There have been contradictory views on the use of innovation by men rather than women (Talukder, 2012).

Furthermore, Muzari et al. (2012) mentioned that assets, incomes, organizations, vulnerability, knowledge, work and creativity of small-scale farmers are factors that influence technology adoption. Technology which needs little asset is less risky and less costly has a greater chance of being used by small farmers.

\subsection{Recommendation technology mechanization}

Oil palm plantation operation such as planting, manuring, inspection and harvesting are all requires dense numbers of manual labour (Dileep Kumar et al.,
2014) that in need of intense physical strength with specific skills and technique. As such, human labour requires lots of working hours and a dense schedule especially in peak harvesting season to cover all the plantation area in order to gain high productivity. All the working hours and hard work labour will increase the plantation operation cost in terms of labour salary and cause operation constraints if the numbers of workers are deficient. Numbers of constraints variables arise in plantation operation concerning the labour's skills such as lack of harvesting technique which can reduce the bunches quality and crop yield, health issues due to common sickness such as fever and flu or occupational hazard like critical injuries due to incidence resulted from the negligence of using heavy and sharp tools (Nawi et al., 2016) and also the shortage of workers especially the foreign worker as stated in Crowley (2020). Thus, to counter all these shortcomings, the recommendation of technology mechanization is vital to ensure efficient plantation operation. As stated in Parveez (2021), the involvement of technology and innovation plantation operations will boost the competitiveness of the oil palm industry both nationally and globally. Furthermore, mechanizing field operation initiated by the Malaysian Palm Oil Board (MPOB) aims at reducing the dependency on workers requirement and overcoming labour shortage due to high competency of labour worker demand due to Malaysia's nation status. The evolution then in return able to increase the plantation productivity and reducing the operation cost (MPOB and Board, 2014). In purchasing technology and machinery in a small scale plantation, the equipment needs to be "scale-appropriate" to ensure high return to land and labor (Mottaleb et al., 2016). The farmers need to calculate and determine the ownership, operating, maintenance and labor cost with the technology application and also consider other variables such as the weather, land acres, risk management and labor supply to meet the utilization of specific technology in the oil palm plantation (Edwards, 2017).

\subsubsection{Motorized cutter (Cantas)}

The most crucial process in plantation operation lies in the harvesting operation which determines the overall plantation yield. Thus, effective harvesting can be achieved with two methods, namely the use of efficient and sufficient harvesters to complete the process during the harvest cycle of 10 to 12 days. However, the difficulty of getting skilled harvesters is a serious constraint that needs serious attention (Dileep Kumar et al., 2014). Proactive measures need to be sought so that harvest productivity can be significantly increased. Conventionally harvesting is done using manual tools (chisel or sickle), however, this method only produces 
average productivity of 2 tonnes per day. Alternatives such as harvesting technology in the oil palm industry are currently in need to double the productivity gain while reducing the number of manual workers. To counter the deficiency, FFB productivity needs to be increased to 4 tonnes per day in order for the country to reduce the amount of labour needed on the field (Jelani et al., 2016).

One of the steps taken by MPOB in 2006 is by launching a motorized cutter shown in Figure 1 known as Cantas for intermediate height palms (less than $5 \mathrm{~m}$ ), and this tool is now being adopted by industry (Shuib et al., 2018). The invention is able to perform fast cutting procedures (Shuib 2016) which can reduce the duration of working hours and enhance plantation operation productivity. Cantas can be used for pruning and harvesting as the technology is specially patented as Csickle, which performs a vibrating cutting mechanism to ease the harvesting operation (Shuib et al., 2018). Trials conducted on Cantas showed that the machine is efficient to cut 560 to 750 bunches a day as compared to the productivity of manual harvesting (using a conventional sickle) which is only 250 to 350 bunches per day (Firdaus et al., 2018). A study by Bakar et al. (2018) concluded that the time taken to complete the overall task for Cantas practices is better than the manual practices. In comparison, workers could only work 5 hours per day for manual harvesting due to energy exhaustion, but Cantas can operate up to 8 hours because it requires less manpower during operation. Additionally, effective field capacity (EFC) for manual harvesting operation is recorded at 0.22 hectare per hour as compared to 0.29 hectare per hour recorded by Cantas operation. Hence, it is proven that the EFC for Cantas is greater than the manual harvesting operation. Moreover, it can save labour deployment and time required for harvesting operation as Cantas utilization enhances the farmers' productivity. Also, both methods can be seen to have a distinct performance. The motorized tool can get until 7.4 tonnes FFB per day as compared to a manual operation which can only get 4.21 tonnes per day. Moreover, the productivity of Cantas corresponds equally to 2 to 3 human power. In short, the smallholders would be able to lessen their labour demand and requirement by $50 \%$ (Firdaus et al., 2018).

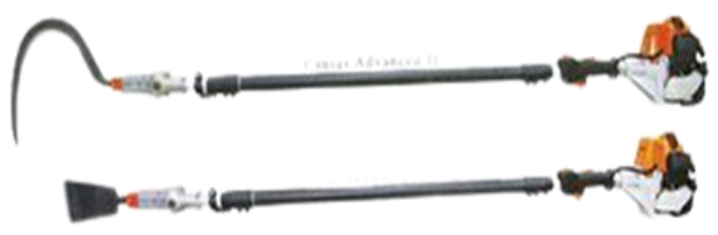

Figure 1. Motorized Cutter (Cantas)

Nonetheless, shortcomings of the Cantas utilization are recorded and stated in various studies. Noraiman et al. (2019) suggested the equipment are not user friendly. Other shortcomings are noise pollution, heavy, limited height reach and also the negative side effect of the vibration on human bodies (KHALID, 2020). Harvesting operation conducted by using Cantas involving high palm trees and frond pruning requires large forces that also hastens machine vibration. High vibration and longtime exposure of the vibration on harvester expose them to a syndrome named the Hand-Arm Vibration Syndrome (HAVS). It is a syndrome where the patient will feel fingers numbness, and eventually become reddish, painful and blanched, weakened hand grip due to deficiency of forces (Md Salleh et al., 2014). This shows that, a long term exposure toward the machine utilization, on daily basis will affect worker's health and condition. Besides, another constraint in Cantas utilization involves operation cost as daily routine inspections are necessary for Cantas to ensure that the cutter is fully capable of harvesting. The total cost of Cantas operating and maintenance costs are more expensive which is RM64.98 per day as compared to manual sickle that costs RM 42.69. However, the cost per tonne for Cantas is significantly cheaper which is RM 8.78 per tonne where RM10.14 per tonne is recorded for manual sickle (Bakar et al., 2018). As for the machine economics, the harvesting cost is around RM $22.10 \mathrm{t}-1$ based on the machine cost of RM 4500 per unit plus its operating, repair and maintenance costs. At RM $0.70 \mathrm{t}-11$, the cost-effectiveness was calculated (Firdaus et al., 2018). Thus, it can be concluded that Cantas is cost effective for harvesting because it is considerably lower than manual. Despite the manual cost is significantly higher, the company still wants manual labor in certain areas to perform harvesting operations.

\subsubsection{Roller picker}

Harvesting FFB in the oil palm plantation is a vital operation that needs to be handled with good management and specific knowledge in order to gain a high oil extraction rate (OER). To manifest higher yield, harvesting the FFB needs to be done at their peak of ripeness. There is 2 ordinary method currently implemented to identify the ripeness of the bunches, firstly by observing the colour index shown by the bunches directly (Kassim et al., 2012) and the presence of loose fruits (LF) on the ground. LF presence is sourced from matured bunches that detached its fruits and LF that scattered on the ground during the harvesting process (KHALID, 2020). If inspection shows one to ten observable LF on the ground scattered in radius of 1.5$2.5 \mathrm{~m}$ from the oil palm tree, it indicates that the harvesting operation can be performed instantly (Awaludin et al., 2016). Darius and Muhammad (2014) stated that loose fruits lead to the maximum OER ratio of 
$40 \%$ per weight, which is equivalent to $\mathrm{FFB}$ at an OER ratio of 20 to $25 \%$ per weight. The loose fruit collection is an important operation as it has the highest oil content, in conjunction with the properties held by the LF that is not polluted and properly handled (Fadilah et al., 2012; Mohd Khalid and Abd Shuib, 2014; Sharif et al., 2017).

Conventionally, loose fruit was gathered by hand or raking. Not only is this procedure demanding and timeintensive, but also it is often repetitive and highly laborious. On average, the worker takes about $28 \%$ of the overall harvest period to gather loose fruits (Shuib et al., 2017). This study coincides with Jelani et al. (2016) proposing that work of collecting loose fruit is done manually where this work is burdensome, tiring and a risk to their health. This is because, during the collection process, the worker would squat and stand up in repetitive numbers every day, causing health issues such as severe back pain and muscle cramp. Furthermore, the conventional method results in low LF collection of only $200 \mathrm{~kg}$ per working day while the work of collecting LF is supposed to make up $28 \%$ of the total harvesting operation. To increase the collection rate, equipment such as scrapers are utilized and the collection of LF can reach about $300 \mathrm{~kg}$ per day. However, this method poses a constraint in terms of low-quality LF as they are mixed with soil or debris. In fact, the separation process afterwards needs to be done meticulously which is tedious and time-consuming.

According to the importance of LF collection, in 2009 MPOB has developed several methods to ease and facilitate LF collection and increase operational efficiency. One of the methods introduced is a mechanical device namely the Roller Picker (RP) as shown in Figure 2, which uses mechanical wheels to collect LF that are scattered under the palm trees (Jelani et al., 2016). The Loose Fruit Picker style Roller represents a different system mechanically harvesting the loose fruits with a lightweight, simple and small structure. The roller picker is built with the specification of an oval case and made up of most wires and rods without the presence of a motor. Field trial conducted in (Yusoff et al., 2019) by using the RP showed the mechanism is able to be utilized in various geographical field conditions due to the adaptability of its structural design in exhibiting decent operation manoeuvrability. The main objective of the technology aims at gathering all the LF on the ground using a simple hand-picking mechanism without bruising the LP (Yusoff et al., 2019).

According to Deraman et al. (2009), the roller picker was capable of gathering LF, depending on the ground conditions in an average of 1 working hour, 30 to $60 \mathrm{~kg}$ of LF were collected and a field test conducted by Che Jaafar and Hashim (2009) stated that this method recorded $95 \%$ of the overall collection of LF. The pros of the equipment are that the fruits are able to be gathered without damaging the LF and clean from a mixture of soil and debris. Studies by Jelani et al. (2016) and Yusoff et al. (2019) indicated that the vertical utilization of the equipment is able to prevent the operator to perform squatting posture in harvesting the LF which eventually could prevent any industrial injuries. There are also other mechanisms available in performing LF collection such as mechanical loose fruit collector (MK I), motorized RP and robotic RP mechanism. All the technology aligned with the Industrial Revolution 4.0 principle that utilizes the Internet of Things (IoT) security and artificial intelligence could effectively increase the field operation, however, the technology will require high purchasing costs. Hence, it might not be affordable by smallholders and reverting the focus to the RP as the mechanism significantly has lower maintenance and is user-friendly. Furthermore, as stated by Abd Manaf and Ariffin (2010) and Hashim (2009), the cost of operation is only below RM150 per unit which is viable for the oil palm sector in general. This mechanism is practically convenient and economically relevant since LF can easily be picked and harvested from the ground and debris-free (Jaafar et al., 2009).

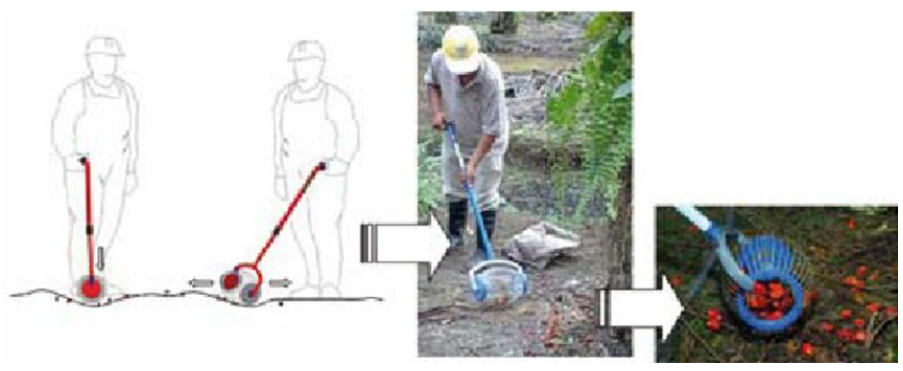

Figure 2. Roller Picker

\section{Conclusion}

In conclusion, the extension agent plays an important role in agricultural technology transfer as they have the technical ability in delivering good communication, comprehension skills to convey mutual attachment and understanding to the independent oil palm growers. Extension agent, acquired with diverse understanding regarding oil palm planting, friendly attitude and personality towards farmers, along with leadership and demonstration technology for oil palm agriculture skills makes them more approachable and accepted by the smallholders. Numbers of studies and findings have proven the advantages of technology transfer by the extension agent in terms of introduction of scheme availability that helps grower's finance in purchasing operation inputs, newly developed technology application and speeding up knowledge regarding crop processing, harvesting techniques, stimulant preparation, and better agricultural techniques. Although technical 
knowledge about oil palm guidelines and advisory programmes have been proposed, small farmers on their farms have adopted good agricultural practices. The current oil palm productivity has increased a lot on average as compared to the previous year. However, some independent small farmers pay less attention to pesticides, insects and parasites, and causing them to have lower plantation productivity. Therefore, the presence of TUNAS under

Malaysian Palm Oil Board (MPOB) will help to enhance the productivity and socio-economic status of smallholders. Developing improvement of smallholders assisted by excellent training and guidance will help to increase the acceptance and dissemination of agricultural knowledge and eventually increase the yield productivity of smallholders. Moreover, the recommendation of technology mechanization to smallholder plantations such as Cantas and Roller Picker that meet the smallholders' scope help to save labour consumption, increase their oil palm productivity, and enhance the farm's coverage of working areas. All in all, it is concluded that the impact of agricultural technology transfer has positively improved farmers' theoretical inputs on plantation operation, technology and helped in raising the production among the independent smallholders.

\section{References}

Abazue, C.M., Er, A.C., Ferdous Alam, A.S.A. and Begum, H. (2015). Oil Palm Smallholders and Its Sustainability Practices in Malaysia. Mediterranean Journal of Social Sciences, 6(6), 482-488. https:// doi.org/10.5901/mjss.2015.v6n6s4p482

Abd Manaf, Z. and Ariffin, A. (2010). Program Pemimpin bersama Pekebun Kecil Sawit - Menteri KPPK Turun Padang ke Kota Marudu. Warta Sawit 44/2010. [In Bahasa Malaysia].

Abd Manaf, Z., Kannan, P., Ishak, S. and Mat Taib, H. (2017). Socio-economic of oil palm replanting by independent smallholders. In Kushairi, A.D., Balu, N. and Ismail, A. (Eds.) Oil Palm Replanting: Little Steps to a Giant Leap. Kajang, Selangor: MPOB, Bangi.

Abdul Wahab, M.R., Ahmad Zakaria, R.M, Hadrawi, M. and Ramli, Z. (2018). Selected Topics on Archaeology, History and Culture in the Malay World. Switzerland: Springer.

Abdullah, F.A. and Samah, B.A. (2013). Factors impinging farmers' use of agriculture technology. Asian Social Science, 9(3), 120-124. https:// doi.org/10.5539/ass.v9n3p120

Abdullah, R. (1991). Malaysia Bumi Bertuah - Kelapa
Sawit. Petaling Jaya, Malaysia: Penerbit Prisma Sdn Bhd.

Abu Samah, B., Shaffril, H.A.M., Hassan, M.S., Abu Hassan, M. and Ismail, N. (2009). Contribution in Increasing Agro-based Entrepreneurs Productivity in Malaysia. Journal of Agriculture and Social Sciences, 5, 93-98.

Ain Sophia, Z., Mohd Fauzie, J. and Mohammad Amizi, A. (2017). Participation of the Oil Palm Smallholders Toward the Implementation of Mechanization in Oil Palm Plantation. International Journal of Agriculture, Forestry and Plantation, 5, 1 -6 .

Al-Shadiadeh, A.N.H. (2007). Descriptive study of the training needs for men and women farmers in semi desert areas a case study of South Jordan. World Applied Sciences Journal, 2(1), 12-21.

Anderson, J.R. and Feder, G. (2003). Rural extension services. Policy Research Working Paper No. 2976. World Bank e-Library. https://doi.org/10.1596/18139450-2976

Aniedu, C., Nwachukwu, I., Uwakah, C.T. and Unamma, R.P. (2007). Gender factors influencing adoption of Yam minisett technique by farmers in South-Eastern Nigeria, Implication for Sustainable Yam Production. Journal of Agriculture and Social Research, 7(2), 30-37. https://doi.org/10.4314/ jasr.v7i2.2854

Aremu, P., Kolo I., Gana A. and Adelere F. (2015). The crucial role of extension workers in agricultural technologies transfer and adoption. Global Advanced Research Journal of Food Science and Technology, 4(2), 14-18.

Armstrong, M. (2003). A Hand Book of Human Resource Management Practice. $9^{\text {th }}$ ed., p. 979. Londan: Kogan Page Ltd.

Asiabaka, C.C. (2002). Promotion sustainable extension approaches: Farmer Field School (FFS) and role in sustainable agricultural development in African. International Journal of Agriculture and Rural Development, 3, 46-53. https://doi.org/10.4314/ jasr.v7i2.2854

Awang, A.H., Hashim, K., Ramli, Z. and Ibrahim, I. (2016). Agricultural Technology Transfer and Productivity of Independent Oil Palm Smallholders. In Proceeding of Academics World $55^{\text {th }}$ International Conference, p. 2-6. Vienna, Austria.

Awang, A.H., Hashim, K., Ramli, Z., Lyndon, N., Ibrahim, I., Tan, S.P., Johari, M.A., Basaruddin, N.H., Abdul Hamid, M.H. and Yusof, I. (2016). Pemindahan teknologi dan produktiviti pekebun kecil persendirian sawit di Teluk Intan, Perak. E- 
Bangi: Journal of Social Sciences and Humanities, 11(1), 78-87.

Azian, F.U.M., Awang, A.H., Ibrahim, I., Ramli, Z., Lyndon, N., Yusof, I., Hashim, K., Tan, S.P., Johari, M.A., Basaruddin, N.H. and Abdul Hamid, M.H. (2017). Kelestarian penanaman sawit dan produktiviti pekebun kecil persendirian. Journal Global Business and Social Entrepreneurship (GBSE), 1(1), 12-20. [In Bahasa Malaysia].

Azman, I., Zulhusni, A., Norhidayu, A., Mashani, S., Khairuman, H., Ainul S. and Balu, N. (2018). Labour Requirements in the Independent Oil Palm Smallholder Sector in Peninsular Malaysia. Oil Palm Industry Economic Journal, 18, 41-49.

Bakar, M.A., Rashid, N.F.A. and Syahlan, S. (2018). Comparison of an effective working hour and harvesting cost between manual harvesting (chisel and sickle) and mechanised harvesting (CKAT and motorised cutter) in oil palm plantation. International Journal of Engineering and Technology (UAE), 7(2), 282-286. https:// doi.org/10.14419/ijet.v7i2.29.13333

Becker, G.S. (1962). Investment in human beings. The Journal of Political Economy, 70(5), 9-49. https:// doi.org/10.1086/258724

Boyd, B.L. (2003). Competencies for leaders of volunteers during the next decade: A national Delphi study. Journal of Agricultural Education, 44, 47-57. https://doi.org/10.5032/jae.2003.04047

Chan, C.S., Mohd Zainal, I. and Abu Hassan, D. (2013). Agricultural Machinery and Mechanization Development in Malaysia. Retrieved from website: http://un-csam.org/sites/default/files/2021-01/5.pdf

Che Jaafar, N. and Hashim, H.K. (2009). Pensijilan RSPO untuk Pekebun Kecil. Warta Sawit 43/2009. 2 -3. [In Bahasa Malaysia].

Coombs, P.H. and Ahmed, M. (1974). Attacking Rural Poverty: How Non-Formal Education Can Help. Baltimore, USA: Johns Hopkins University Press.

Cristóvão, A., Koutsouris, A. and Kügler, M. (2012). Extension Systems and Change Facilitation for Agricultural and Rural Development. In Darnhofer, I., Gibbon, D. and Dedieu, B. (Eds.) Farming Systems Research into the 21st Century: The New Dynamic, p. 201-227. Dordrecht, The Netherlands: Springer Science. https://doi.org/10.1007/978-94007-4503-2 10

Darius, E.P. and Muhammad, F.H. (2014). Effects of Collecting Systems and Plantation Environment in Debris Accumulation in a Collected Oil Palm Loose Fruit. Proceedings of the International Conference on Plant Physiology, 2015, 147-151
Department of Statistics Malaysia. (2015). The breadth of oil palm plantations, palm oil production and palm oil prices in Malaysia from 2010 to 2014. Putrajaya, Malaysia: Department of Statistics.

Deraman, M.S., Shuib, A.R. and Jaafar, M.S. (2009). Roller-type oil palm loose fruit picker. MPOB Information Series No. 419. Malaysia: MPOB.

Dhanakumars, V.G. (2001). Performance appraisal in Rubber Board Extension Delivery Systems (RBEDS). Journal of Agricultural Extension Management, 2, 174-190.

Edwards, W. (2017). Farm Machinery Selection | Ag Decision Maker. Retrieved January 12021 from Iowa State University - Extension and Outreach: https://www.extension.iastate.edu/agdm/crops/html/ a3-28.html

Fadilah, N., Saleh, J.M., Ibrahim, H. and Halim, Z.A. (2012). Oil palm fresh fruit bunch ripeness classification using artificial neural network, presented at the 4th International Conference on Intelligent and Advanced Systems (ICIAS2012), p. 18-21. Kuala Lumpur, Universiti Teknologi Petronas.

ICIAS.2012.6306151

FAO. (2001). Farmer innovation and new technology options for food production, income generation and combating desertification. Progress Report 2001. Retrieved from FAO website: https://www.fao.org/in -action/promoting-farmer-innovation-and-ffs-inkenya/en/

FAOSTAT (Food and Agriculture Organization of the United Nations Data). (2016). Rome, Italy: FAO. Retrieved on June 12, 2017 from FAO website: http://faostat3.fao.org/home/E.

Farouque, M.G. and Takeya, H. (2007). Resource-Poor Farmers' Constraints regarding Integrated Soil Fertility and Nutrient Management for Sustainable Crop Production: A farm level study in Bangladesh, presented at the $106^{\text {th }}$ Seminar, October 25-27, 2007. Montpellier, France: European Association of Agricultural Economists.

Fauziah, A., Siti, M.A., Ayatollah, K., Anis, M., Raja, Z.R.O. and Zulkifli, A.M. (2018). Economic benefits of oil palm replanting. In Kushairi, A.D., Balu, N. and Ismail, A. (Eds.) Oil Palm Replanting: Little Steps to a Giant Leap, p. 79-95. Kajang, Selangor: MPOB, Bangi.

Feder, G., Murgai, R. and Quizon, J.B. (2004). The acquisition and diffusion of Knowledge: The case of pest management training in farmer field schools, Indonesia. Journal of Agricultural Economics, 55(2), 221-243. 
9552.2004.tb00094.x

Firdaus, M., Aziz, A., Firdaus, M. and Aziz, A. (2018). Mechanization in Oil Palm Harvesting Mechanization in Oil Palm Harvesting, 8(5), 247256. https://doi.org/10.6007/IJARBSS/v8-i5/4098

Godtland, E., Sadoulet, E., Janvry, A.D., Murgai, R. and Ortiz, O. (2003). The impact of farmer-field-school on Knowledge: An empirical study of potato farmers in the Peruvian Andes. Economic Development and Cultural Change, 53(1), $1-26$.

Hashim, K., Mansor, N.H., Abu Bakar, H. and Omar, W. (2014). Pusat TUNAS MPOB: Penggerak Perubahan Pekebun Kecil Sawit Persendirian. Prosiding Persidangan Kebangsaan Pekebun Kecil Sawit 2014. P.207-218.

Hayrol Azril, M.S., Md Salleh, H. and Bahaman, A.S. (2009). Level of Agro-based Website Surfing among Malaysian Agricultural Entreprenuers: A Case Study of Malaysia. Journal of Agriculture and Social Sciences, 5, 55-60.

Idris, O., Roslan, A. and Nazirah, C.J. (2007). A Survey on 30-Tonner Club Members to Select Suitable Candidates as MPOB Agents, presented at the Roundtable Discussion on Oil Palm: Narrowing the Yield Gap towards Vision 35:25. Labuan, Malaysia: MPOB.

IFC (International Finance Corporation). (2013). Diagnostic survey of oil palm smallholders in Indonesia: Developing a better understanding of their performance and potential. Washington, D.C, USA: IFC.

Jaafar, N.C., Abdullah, R., Salleh, K.M., Ahmad, M., Bakar, H.A. and Mansor, N.H. (2017). Factors Affecting Membership Of Sustainable Oil Palm Grower Cooperative (KPSM) Among Independent Oil Palm Smallholders in Malaysia. IOSR Journal of Humanities and Social Sciences, 22(8), 12-26. https://doi.org/10.9790/0837-22080101226

Jalani, B.S., Yusof, B., Ariffin, D., Chan, K.W. and Rajanaidu, N. (2002). Prospects of Elevating National Oil Palm Productivity: A Malaysian Perspective. Oil Palm Industry Economic Journal, 2, $1-9$.

Jelani, A.R., Deraman, M.S., Khalid, M.R., Ahmad, M.R., Azaman, M.K.H., Ismail, A. and Shuib, A.R. (2016). Penggunaan Mekanisasi di Ladang Sawit. In Prosiding Persidangan Kebangsaan Pekebun Kecil Sawit 2016. Malaysia: MPOB. [In Bahasa Malaysia]. Jones, G.E. and Garforth, C. (1997). The History, Development, and Future of Agricultural Extension. In Swanson, B.E., Bentz, R.P. and Sofranko, A.J. (Eds.) Improving Agricultural Extension A
Reference Manual, p. 2-12. Rome: FAO.

Kannan, P., Tan, S.P., Ahmad, S.M., Seman, I.A., Ab Rahman, A.K., Hashim, K., Abu Bakar, H. and Omar, W. (2017). Knowledge assessment of basal stem rot disease of oil palm and its control practices among recipients of replanting assistance scheme in Malaysia. International Journal of Agricultural Research, 12(2), 73-81. https://doi.org/10.3923/ ijar.2017.73.81

Kementerian Dalam Negeri Malaysia. (2015). Jumlah pekerja asing di malaysia mengikut sektor, 2000 2015. Retrieved from http://www.epu.gov.my/sites/ default/files/1.5.1.pdf.

Kushairi, A., Loh, S.K., Azman, I., Hishamuddin, E., Ong-Abdullah, M., Mohd Noor Izuddin, Z.B., Razmah, G., Sundran, S. and Parvee, G.K.A. (2018). Oil Palm Economic Performance in Malaysia and R\&D Progress in 2017. Journal of Oil Palm Research, 30, 163-195.

Lamble, W. (1984). Diffusion and Adoption of Innovations. In Blackbourn, D. (Ed.) Extension Handbook, p. 32-41. Guelf, Canada: University of Guelf.

Leeuwis, C. and Van Den Ban, A.W. (Eds.) (2004). Communication for Rural Innovation: Rethinking Agricultural Extension. $3^{\text {rd }}$ ed. Oxford, United Kingdom: Wiley-Blackwell.

Liles, R.T. and Mustian, R.D. (2004). Core competencies: A systems approach for training and organizational development in extension. The Journal of Agricultural Education and Extension , 10(2), 77-82. https:// doi.org/10.1080/13892240485300121

Linders, J.R. (2001). Competency assessment and human resource management performance of county extension chairs in Ohio. Journal of Agricultural Education, 42(4), 21-31. https://doi.org/10.5032/ jae.2001.04021

Malaysia Palm Oil Board (MPOB) (2016). Overview of The Malaysian Oil Palm Industry 2015. Retrieved December 20, 2020 from MPOB website: http:// palmoilis.mpob.gov.my/V4/wp-content/ uploads/2020/03/Overview_of_Industry_2015.pdf

Mariyono, J. (2009). Integrated pest management training in Indonesia: Does the performance level of farming training matter?. Journal of Rural and Community Development, 4, 93-104.

Mariyono, J. (2011). Double gains in productivity: Impacts of integrated pest management technology on productions of rice and soybean in Java. Journal of Agricultural Technology, 7(1), 19-28.

Maunder, A.H. (1972). Agricultural Extension: A 
Reference Manual. Rome: FAO.

Mohd Ishak, S. and Abd Manaf, Z. (2020). Influence of Knowledge, Attitude and Skill on Good Agriculture Practices of Seedling Assistance Scheme Participant toward Oil Palm Production in Sabah and Sarawak. Oil Palm Industry Economic Journal, 20, 12-20.

Mohd Khalid, M.R. and Abd Shuib, R. (2014). Oil palm mechanisation: Recent technologies and challenges, presented at the National Conference on Agricultural and Food Mechanisation, p. 404-412. Sabah, Malaysia.

MPOB (2017). Malaysian Oil Palm Statistics 2016. $36^{\text {th }}$ ed. Kuala Lumpur, Malaysia: MPOB.

MPOB (2018). Malaysian Oil Palm Statistics 2017. $37^{\text {th }}$ ed., p. 205. Kuala Lumpur, Malaysia: MPOB.

MPOB (2019). Factsheet Pekebun Kecil Sawit Disember 2018. Kuala Lumpur, Malaysia: Integration Research and Extension Division (IRED), MPOB.

Muzari, W., Gatsi, W. and Muvhunzi, S. (2012). The Impacts of Technology Adoption on Smallholder Agricultural Productivity in Sub-Saharan Africa: A Review. Journal of Sustainable Development, 5(8), 69-77. https://doi.org/10.5539/jsd.v5n8p69

Nagel, U.J. (1997). Alternative Approaches to Organizing Extension. In Swanson, B.E., Bentz, R.P. and Sofranko, A.J. (Eds.) Improving Agricultural Extension A Reference Manual, p. 13-24. Rome: FAO.

Nagiah, C. and Azmi, R. (2012). A Review of Smallholder Oil Palm Production: Challenges and Opportunities for Enhancing Sustainability - A Malaysian Perspective. Journal of Oil Palm and the Environment, 3(12), $114-120$.

Nawi, N.S.M., Deros, B.M., Nordin, N., Ab Rahman, M.N. and Sukadarin, E.H. (2017). Critical factors for oil palm plantation workers acceptance and use of mechanization technovation tools. PressAcademia Procedia, 4, 218-223. https://doi.org/10.17261/ Pressacademia.2017.537

Nurhanani, M., Nazirah, C.J., Ainul, S.S., Mohamad, A.J., Amran, A., Nursuhana, D., Parthiban, K., Tan, S.P., Hasmiza, D., Khairul, A., Shakir, A., Mohd, K.A.I. and Hamdan, A.B. (2016). Penerimaan Guna Amalan Pertanian Baik (GAP) di Kalangan Pekebun Kecil Sawit Persendirian di Malaysia. In Prosiding Persidangan Kebangsaan Pekebun Kecil Sawit 2016. Malaysia: MPOB. [In Bahasa Malaysia].

Nwaobiala, C.U, and Ezeh, C.I (2012). Farmers' Perception of Simple Mechanized Farm Implements used in Crop Production in Abia State, Nigeria. The Journal of Agricultural Sciences, 7, 159-162. https:// doi.org/10.4038/jas.v7i3.4879
Olsen, L., Bhattacharya, J. and Scharf, A. (2006). Cultural Competency: What it is and why it matters. Lucile Packard Foundation for Children's Health. California, USA: California Tomorrow.

Perez, N., van Gelder, J.W., Smit, H. and Pacheco, P. (2016). How can the financial services sector strengthen the sustainability and inclusivity of smallholder farming in the supply of global commodity crops? Exploring the challenges facing the Indonesian oil palm sector and learning lessons from around the world. Presented at the White Paper, 6 June 2016, Royal Society London. London, UK: Global Landscape Forum.

Rezaie, A., Rezvanfar, A. and Alambeigi, A. (2008). Analysis of the job performance of the agricultural extension experts of yazd province, Iran. Journal of Agriculture and Social Research, 7, 1-10. https:// doi.org/10.4314/jasr.v7i2.2851

Rivera, W.M. and Qamar, M.K. (2003). Agricultural extension, rural development and the food security challenge. Rome: Food and Agriculture Organization of The United Nations.

Rogers, A. (1992). Adults learning for development. London, United Kingdom: Cassell Education Ltd.

Rogers, E.M. (2003). Diffusion of innovations. New York, USA: The Free Press.

Roling, N.G. (1982). Alternative Approaches to Extension. In Jones, G.E. and Rolls, M. (Eds.) Progress in Rural Extension and Community Development. Vol. 1, p. 87-115. Chichester: Wiley.

Roxas, S.A., Piroli, G. and Sorrentino, M. (2011). Efficiency and Evaluation Analysis of a Network of Technology Transfer Brokers. Technology Analysis and Strategic Management, 23(1), 7-24. https:// doi.org/10.1080/09537325.2011.537085

Sahidan, A.S., Abdul Rahman, A.R. and Moslim, R. (2019). The impact of social network towards oil palm independent smallholders. Oil Palm Industry Economic Journal, 19, 9-16.

Salako, M.A., Lawrence, A., Aremu, Y.S. and Egbekunle, S.O. (2015). Agriculture, Economic Growth and Development Nexus: Var Variance Decomposition Evidence From Nigeria. International Journal of Economics, Commerce and Management United Kingdom, 3(6), 460-478.

Sharif, Z.M., Taib, N.M., Yusof, M.B., Rahim, M.B., Tobi, A.B.M. and Othman, M.B. (2017). Study on handing process and quality degradation of oil palm fresh fruit bunches (FFB). IOP Conference Series: Materials Science and Engineering, 203, 012027 https://doi.org/10.1088/1757-899X/203/1/012027

Shuib, A.R., Khalid, M.R. and Deraman, M.S. (2018). 
Innovation and technologies for oil palm mechanization. In Further Advances in Oil Palm Research (2000 - 2010), p. 569 - 597. Kuala Lumpur, Malaysia: MPOB.

Shuib, A.R., Khalid, M.R., Bakri, M.A., Mohamed, A. and Salleh, N. (2017). Oil Palm Loose Fruit Collecting Machine with Elevated Discharge Mechanism (LFC Mark IV). MPOB Information Series, No. 612. Malaysia: MPOB.

Stuart, A.M., Prescott, C.V., Singleton, G.R. and Joshi, R.C. (2011). Knowledge, attitudes and practices of farmers on pests and their management in the lowlands of the Sierra Madre Biodiversity Corridor, Philippines. Crop Protection, 30(2), 147-154. https:// doi.org/10.1016/j.cropro.2010.10.002

Swanson, B., and Claar, J. (1984). The History and Development of Agricultural Extension. In Swanson, B. (Ed.) Agricultural Extension: A Reference Manual, p. 1-19. Rome: FAO.

Talukder, M. (2012). Factors affecting the adoption of technological innovation by individual employees: An Australian study. Procedia - Social and Behavioral Sciences, 40, 52-57. https:// doi.org/10.1016/j.sbspro.2012.03.160

Tan, S.P., Hashim, K., Mansor, N.H., Kannan, P., Ariffin, A., Johari, M.A., Abidin, K., Dahari, N., Desa, H. and Isnin, K.A. (2019). Assessment on Knowledge on fertiliser management among independent smallholders in Malaysia. Oil Palm Industry Economic Journal, 19, 1-16.

Truong, T.N.C. (2008). Factors Affecting Technology Adoption among Rice Farmers in the Mekong Delta through the Lens of the Local Authorial Managers: An Analysis of Qualitative Data. Omonrice, 16, 107112.

Van den Ban, A.W. and Hawkins, H.S. (1996). Agricultural extension. $2^{\text {nd }}$ ed. New York, USA: John Wiley and Son Inc.

Vermeulen, S. and Goad, N. (2006). Towards better practice in smallholder palm oil production Natural Resource Issues Series No. 5. London, United Kingdom: International Institute for Environment and Development.

Waddington, H., Snilsveit, B., Hombrados, J., Vojtkova, M., Philips, D., Davies, P. and White, H. (2014). Farmer field schools for improving farming practices and farmer outcomes: A systematic review. Campbell Systematic Reviews, 10(1), 1-335. https:// doi.org/10.4073/CSR.2014.6

Wahid, M.B. and Simeh, M.A. (2009). Issues related to production cost of palm oil in Malaysia. Oil Palm Industry Economic Journal, 9(2), 1-12.
Witt, R., Waibel, H. and Pemsl, D.E. (2006). Diffusion of information among small-scale farmers in Senegal: The concept of farmer field schools. Germany: University of Hannover.

Yew, V.W.C., Awang Besar, J., Azima, A.M., Zaimah, R. and Nambiappan, B. (2016). The sustainability of oil palm industry in Malaysia: A comprehensive review. International Journal of Economic Perspectives, 10(4), 305-310.

Yusoff, M.Z.M., Zamri, A., Kadir, M.Z.A.A., Hassan, W.Z.W. and Azis, N. (2019). Loose Fruit Collector Machine in Malaysia: A Review. International Journal of Engineering Technology and Sciences, 6 (2), 65-75.

Zulkefli, F. and Syahrizan, S. (2017). An Overview of Acceptance and Adoption of Agricultural Innovation and Technology for Sustainable Palm Oil Industry. International Journal of Academic Research in Business and Social Sciences, 7, 355-360. https:// doi.org/10.6007/IJARBSS/v7-i11/3467 